\title{
EFFECTIVENESS OF BACK EFFLUERAGE MASSAGE THERAPY USING CLOVE OIL ON UNDER BACK PAIN IN POSTPARTUM MOTHER
}

\author{
Rini Rahmayanti ${ }^{1 *}$, Yola Yolanda ${ }^{1}$ \\ ${ }^{1}$ Nursing Study Program STIKES MERCUBAKTIJAYA Padang \\ *Correspondence: \\ Rini Rahmayanti \\ Email: rinie.rahmayanti@gmail.com \\ Address: STIKES MERCUBAKTIJAYA Padang, Surau Gadang, Nanggalo, Padang City, West Sumatra 25173
}

\begin{abstract}
Background: Low back pain is one of the complaints felt by most or even almost all postpartum mothers since pregnancy. The prevalence of events ranges from $20-90 \%$ since pregnancy. About $80 \%$ of postpartum mothers experience low back pain after a normal delivery. One type of complementary therapy that can be done to increase the pain threshold is back effluerage massage with clove oil. Cloves contain components of eugenol compounds that have analgesic effects.

Objectives: The purpose of this study was to determine the effectiveness of back effluerage massage therapy using clove oil on lower back pain in postpartum mothers.

Methods: This study uses a Quasi-Experiment method with the design of One Group Pretest-Posttest. The sample in this study was postpartum mothers with vaginal delivery who experienced lower back pain. Consecutive sampling technique will be used to determine the sample. The number of samples taken in this study were 20 people as a treatment group. The instrument used was an observation sheet to determine the pain scale of the respondent. This research will be carried out within one year. The results of the study will be analyzed by paired $\mathrm{T}$ test.

Results: The results obtained $\mathrm{p}$ value 0.005 ( $\mathrm{p}$ value $<0.05$ ) so that there is an effect of back effluerage massage therapy using clove oil on lower back pain in postpartum mothers.

Conclusion: The results of this study are expected to evaluate the effect of back effluerage massage therapy using clove oil on lower back pain in postpartum mothers.
\end{abstract}

Key words: Back Effluerage Massage, Clove Oil, Low Back Pain, Postpartum Mothers.

\section{INTRODUCTION}

The pleasant period of being a mother is felt after the birth of a baby. In addition to feeling happy, mothers also experience complaints that often-become stressors. The mother will experience some discomfort during the postpartum period. Some discomforts experienced by postpartum mothers are fatigue, episiotomy scars, mastitis, afterpain, lower back pain, psychological problems, postpartum hemorrhage and anemia (Mousavi, 2013). Low back pain is one of the complaints felt by almost all postpartum mothers since pregnancy (Febris, 2011). In the world, about $80 \%$ of postpartum mothers experience low back pain after a normal delivery. Lower back pain occurs in 45$55 \%$ of mothers in the first week of postpartum, continuing in 8 weeks postpartum by $68 \%$ and $60 \%$ in the following 8 months (Corso, 2016). In 
Indonesia, $60-80 \%$ of pregnant women experience low back pain during pregnancy, and more than $50 \%$ of complaints persist during the postpartum period (Mafikasari, 2015).

Complaints of low back pain are discomforts that occur under the ribs and above the inferior glueteal (Wahyuni, 2012). Persistent pain causes inhibition of maternal activity and decreases quality of life. The impact is not only felt by the mother but also by the baby, family and community. Complaints of low back pain interfere with the mother's happy period with the baby including breastfeeding6. The postpartum recovery period will last a long time if complaints of low back pain are not treated.

Lower back pain requires the role and comprehensive effort of nurses to intervene to reduce maternal postpartum pain. Management of back pain can be done with non-pharmacological therapy or complementary therapy. Massage is a manual therapy which is the oldest complementary therapy to reduce pain. Back Effluerage Massage is the act of stimulating certain points along the spinal cord meridians that are transmitted through the large nerves to the reticular formation, the thalamus, and the body's limbic system will release endorphins. When doing massage can use massage oil so that the hands are a bit slippery and the mother feels comfortable (Puspitasari, 2010). Clove is an aromatic dried flower and contains a compound of eugenol which has an analgesic effect. Clove oil also has a calming aromatic effect and causes a feeling of relaxation.

Research conducted on postpartum mothers found that there was a significant effect of clove oil massage on the scale of postpartum maternal back pain. Mothers feel comfort when given a massage because of the warmth and aromatic effects of clove oil. Based on the explanation above, the researcher wants to prove the effectiveness of back effluerage massage therapy using clove oil against postpartum maternal lower back pain.

\section{METHODS}

Study Design

This study uses a Quasi-Experiment method with One Group Pretest-Posttest design using treatment groups.

\section{Setting}

This research was conducted in the working area of Padang Nanggalo Public Health Center from March-November 2019 and data collection was carried out on 1017 May 2019.

\section{Research Subject}

The research was begun by collecting respondents from data at the Nanggalo Public Health Center and then researchers going to respondent's homes to provide interventions. The number of samples taken in this study were 20 people as a treatment group. The sample was selected by criteria Inclusion of postpartum mothers willing to become respondents by signing the consent sheet as a respondent and following the research procedure until the final stage, mothers with vaginal delivery, postpartum mothers a maximum of 7 days. And the exclusion criteria were postpartum mothers in high risk groups. The sampling technique is consecutive sampling technique.

\section{Instruments}

The instrument used in this study was a numerical pain intensity scale. The treatment given in this study is giving back effluerage massage therapy using clove oil twice a day in the morning and evening for 30 minutes with $8-10 \mathrm{cc}$ of clove oil within seven days.

\section{Data Analysis}

This research data was processed using computerization. the results of the study were processed with a statistical test $\mathrm{T}$ dependent test with a 95\% confidence level. 


\section{Ethical Consideration}

This research was conducted after obtaining permission from the Padang City Health Office permit with license number 890/3597/SDMK \& Jamker/VI /2019.

\section{RESULTS}

Characteristics of Respondents by Age, and Parity Status

Table 1. Distribution of Frequency of Respondents by Age and Parity Status in the working area of Padang Nanggalo Public Health Center $(n=20)$.

\begin{tabular}{ccc}
\hline Characteristic & Frequency & $\begin{array}{c}\text { Percentage } \\
(\boldsymbol{\%})\end{array}$ \\
\hline Age (year) $\mathrm{M}=29.95, \mathrm{SD}=3.486$, Min=23, Max $=36$ & \\
High risk $(<20$ and $>35)$ & 1 & 5 \\
Normal $(20-35)$ & 19 & 95 \\
\hline Parity M=2.05, SD=0,999, Min=1, Max=5 & \\
Primipara (1) & 7 & 35 \\
Multipara (2-4) & 13 & 65 \\
Grand2multipara (>4) & 0 & 0 \\
\hline Source: Primary data of questionnaire, 2019 &
\end{tabular}

Based on table 1. It can be seen that the average age of the respondents obtained a mean value of 29.95 with a median of 30 and a standard deviation of 3,486 . The age of most respondents is the normal age 2035 (95\%). The average parity of respondents obtained a mean of 2.05 with a median of 2.05 and a standard deviation of 0.999 . The parity of most respondents is multipara 2-4 (65\%).
Average of the Lower Back Pain of the Mother Postpartum Before and After Giving Back Effluerage Massage Therapy using Clove Oil

Table 2. Average of the Lower Back Pain of the Mother Postpartum Before and After Giving Back Effluerage Massage Therapy using Clove Oil in the Working Area of Padang Nanggalo Public Health Center (n $=20)$.

\begin{tabular}{ccccc}
\hline Pain Scale & Mean & SD & Min & Max \\
\hline Pretest & 6.05 & 0.826 & 5 & 7 \\
Posttest & 2.06 & 0.681 & 2 & 4 \\
\hline \multicolumn{2}{l}{ Source: Primary data of questionnaire, 2019}
\end{tabular}

Source: Primary data of questionnaire, 2019

Based on table 2. shows that the average pain scale before back effluerage massage therapy using clove oil is 6.05 with a standard deviation of 0.826 . The maximum pretest pain scale is 7 and the minimum is 5 in postpartum mothers. The average pain scale after back effluerage massage therapy using clove oil is 2.06 with a standard deviation of 0.681 . The maximum pretest pain scale is 4 and the minimum is 2 in postpartum mothers.

Examination of The Effectiveness of Back Effluerage Massage Therapy Using Clove Oil to Reduce Lower Back Pain in Postpartum Mothers

Table 3. Examination of The Effectiveness of Back Effluerage Massage Therapy using Clove Oil to Reduce Lower Back Pain in Postpartum Mothers with A Statistical Analysis Dependent T Test $(\mathrm{n}=20)$.

\begin{tabular}{cccccc}
\hline Pain Scale & Mean & N & SD & $\begin{array}{c}\text { Diff } \\
\text { mean }\end{array}$ & $\begin{array}{c}\text { P } \\
\text { Value }\end{array}$ \\
\hline Pretest & 6.05 & 20 & 0.826 & 3.450 & 0.005 \\
Posttest & 2.06 & 20 & 0.681 & & \\
\hline \multicolumn{5}{l}{ Source: Primary data of questionnaire, 2019}
\end{tabular}

Source: Primary data of questionnaire, 2019

Based on table 3. shows the statistical test results using paired sample T-test $\mathrm{p}$ values obtained $0.005(p \leq 0.05)$. The results of the study of 20 respondents obtained the average value of pain intensity 
before being given back effluerage massage therapy using clove oil is 6.05 and after being given back effluerage massage therapy using clove oil is 2.06 with mean different is 3.450 .

\section{DISCUSSION}

Based on the result of research, it can be seen that the average age of the respondents obtained a mean value of 29.95 with a median of 30 and a standard deviation of 3,486 . The average parity of respondents obtained a mean of 2.05 with a median of 2 and a standard deviation of 0.999 . Women who give birth more than once or multiparous have a higher risk for experiencing low back pain during postpartum. Risk factors for the emergence of low back pain in postpartum mothers include a history of back pain before pregnancy, a history of a previous pregnancy, heavy work, multipara, a history of back trauma.

Postpartum mothers experience low back pain on a moderate to severe scale. The main complaint that is often found in postpartum mothers is low back pain. Low back pain is pain that is confined to the lumbar region, but the symptoms are more evenly distributed and are not limited to one nerve root, but are broadly derived from the lumbar intervertebral discs. Complaints of low back pain are discomforts that occur under the ribs and above the inferior glueteal part. Lower back pain in postpartum mothers is defined as pain that is recurrent or persistent for more than one week in the area of the spine during pregnancy and continues after pregnancy or during the postpartum period (Fabris 2011).

Pain is a sensation of discomfort that is individual. Pain is influenced by a person's endorphin levels, the higher the endorphin levels, the lighter the pain felt. Endorphin production can be increased through skin stimulation (Corso, 2016).

Based on paired sample T-test, $\mathrm{p}$ values obtained $0.005(\mathrm{p} \leq 0.05)$. The results of the study of 20 respondents obtained the average value of pain intensity before being given back effluerage massage therapy using clove oil is 6.05 and after being given back effluerage massage therapy using clove oil is 2.06 with mean different is 3.450 .

One of the skin stimulations is back effleurage massage therapy using clove oil. Previous research conducted by Netnravathi \& Vijaitha (2015), carried out clove oil therapy given for 3 days in the morning and evening with a duration of 5-6 minutes as much as $8-10 \mathrm{ml}$ of clove oil. Giving with this time effectively reduces the intensity of low back pain in postpartum mothers (Mafikasari, 2015). Massage using oil 24 hours after postpartum is a traditional method used to relieve back pain. The use of cloves has been recommended for toothache and anti-joint pain medications. is an aromatic dried flower and contains a component of the eugenol compound which has an analgesic effect. The composition of Eugenol is around $72-90 \%$ of clove extract. Clove. Clove oil also has a calming aromatic effect and causes a relaxed feeling (Parik, 2016).

In line with research conducted by Richard (2017) on the effectiveness of effleurage techniques and warm compresses on reducing back pain in pregnant women at the Pesantren 1 Puskesmas Kota Kediri, the results of effleurage techniques and warm compresses effectively reduce back pain, there is no difference in the effectiveness of the two therapies so that both techniques can be used to reduce back pain in third trimester pregnant women (Puspitasari, 2010).

Back effluerage massage therapy is massage on the back using the palm of the hand that puts gentle pressure on the surface of the body in a circular direction repeatedly. The massage starts from the lower waist to the shoulder with movements like a butterfly. This therapy stimulates certain points along the spinal cord meridians that are transmitted through 
the large nerves to the reticular formation, the thalamus, and the body's limbic system releasing endorphins. Endorphins are neurotransmitters or neuromodulators that inhibit the delivery of pain blocks by attaching to the opiate receptors in the nerves and spinal cord so that they can block pain messages to a higher center and can reduce pain sensation (Nethravathi, 2015).

The effects of massage therapy given to the body including back effluerage massage will cause more objective physiological changes such as heart rate, blood pressure and cortisol levels) and psychological, more subjective changes such as mood, well-being and stress). Certain effects of therapy such as decreased pain, increased range of motion and muscle relaxation. Back effluerage massage can minimize pain because it can relax muscle tension that stimulates pain and when doing therapy, the mother breathes slowly so that she feels comfortable and can turn her attention to pain (Speziali, 2015). The results showed that back effluerage massage therapy using clove oil can be used as an alternative choice to reduce the intensity of pain in the lower back of the mother's postpartum.

\section{CONCLUSION}

Based on the results of research on back effluerage massage therapy on the intensity of low back pain in postpartum mothers, it can be concluded that there is an effect of back effluerage massage therapy using clove oil on lower back pain in postpartum mothers with $p$ value 0.005 .

\section{SUGGESTIONS}

The results of this study suggest that health workers can use complementary therapy, namely effleurage massage with clove oil to reduce low back pain in postpartum mothers.

\section{ACKNOWLEDGMENT}

A big thanks from the researchers to the Ministry of Science, Research,
Technology and Higher Education of Indonesia (KEMENRISTEKDIKTI RI), who have supported this research, to the academic community of STIKes Mercubaktijaya Padang who have supported the researchers to conduct this research and to the Nanggalo Padang Health Center who have given permission for this research.

\section{DECLARATION OF CONFLICTING INTEREST}

No potential conflict of interest was reported by the authors.

\section{FUNDING}

This research funding comes from the Ministry of Science, Research, Technology and Higher Education of Indonesia in national competitive research which is only in the beginner lecturer research in 2018 .

\section{AUTHOR CONTRIBUTION}

Rini Rahmayanti: Prepare research proposals, Conducting, research permit, promote research plans at the Public Health Center, selecting samples based on inclusion and exclusion criteria, collecting pretest and posttest data, intervening back effleurage back therapy using clove oil, and compile research report, presentation of results report.

Yola Yolanda: Conduct preliminary studies, assist in preparing proposals, help make arrangements for a research permit, helps collect research data, perform data processing, help compile research results reports, and assist in the preparation of publications and manuscripts.

\section{ORCID}

Rini Rahmayanti

None.

Yola Yolanda

None. 


\section{REFERENCES}

Angelo, A., Silva, D., Zambaid, C.,\& Cantilino, A., Sougey, E. (2014).Influence of body posture on the association between postpartum depression and pain. Trends Psychiatry Psychother. 36(1).32-39.

Black \& Hawks, (2009). Medical surgical nursing: clinical management for continuity of care. $8^{\text {th }} \mathrm{ed}$. Philadelphia: W.B. Saunders company.

Corso, M., Grondin, D., Weis, C. (2016). Postpartum low back pain: it is not always what you think. Obstetrics and Gynaecology Cases Review.3(3). 1-5.

Fabris, K. (2011). Persistent postpartum pain after vaginal birth and caesarean section.

Periodicum

Biologorum.113(2).239-241.

Kshoshno, H., Mohammadi, F., Dalvandi, A.,\& Azad, M. (2016). The effect on massage duration on sleep quality improvement. Iranian Journal Of Rrehabilitation Research in Nursing. 2(4), 10-18.

Lowdermilk, B., Perry., Cashion. (2013). Lowdermilk, B., Perry., Cashion. (2013). Keperawatan Maternitas. Edisi 8, buku Jakarta: Salemba Medika.

Mafikasari., \& Kartikasari, (2015). Posisi tidur dengan kejadian back pain (nyeri punggung) pada ibu hamil trimester III. Surya. 7(2).26-34.

Mousavi, S., mortazavi, (2013). Quality of life after cesarean and vaginal delivery. Oman Med Journal. 28(4).245-251.

Nethravathi, V., \& Vijaitha, V. (2015). Effectiveness of Clove oil massage on lower back pain among post natal mother at selected hospital Bangalore. Asian Journal Nursing Education and Research, 5(4). 467-470.

Nowak, K., Ogonowski, J., Haworska, M.,\& Grzesik, K. (2012). Clove oil, proppertier and application. Chemik. 66(2). 145-152.

Ozgoli, G., Torkashvand, S., Salehi Moghaddam, F., Borumandnia, N., Mojab, F., \& Minooee, S. (2016).
Comparison of peppermint and clove essential oil aroma on pain intensity and anxiety at first stage of labor. The Irian Journal of Obstetric, Gynecology and infertility, 19 (21), 1-11.dst.

Parik., \& Joshi, (2016). Prevalence of low back pain and its impact on quality of life in post partum women. International Journal of Recent Scientific Reseach. 7(11). 1424214348.

Pilliteri, A. (2010). Pilliteri, A. (2010). Maternal and Child Health Nursing. Philadelpia: Lippincott.

Puspitasari, I. Astuti, D. (2010). Teknik massage punggung untuk mengurangi nyeri persalinan kala I. Jurnal Ilmu Keperawatan dan Kebidanan. 8(2).100-106.

Speziali, A., Tei, M., Placella, G., Chillemi, M, \& Cerulli,G. (2015) Postpartum sacral stress fracture: an atypical case report. Case Rep Orthop, 2(3).200-207.

Wahyuni., \& Prabowo, (2012). Manfaat Kinesiotapping untuk mengurangi nyeri punggung bawah pada kehamilan trimester ke-3. Jurnal Kesehatan.5(2).119-129.

Webb,D., Cloch, J., Coyne, J., Chung, E., Bennet, I., Culhane, F. (2014). Postpartum physical syntoms in new mother: their relationship too functional limitation and emotional well being. NIH Public Access, 35(3).

Cite This Article As: Rahmayanti, R., \& Yolanda, Y. Effectiveness of Back Effluerage Massage Therapy using Clove Oil on Under Back Pain in Postpartum Mother. Nurse and Health: Jurnal Keperawatan 2019; 8(2): 72-77. 